Penelitian

\title{
Pola Perkawinan dan Estimasi Kelahiran Berdasarkan Hasil Diagnosis Kebuntingan Sapi Bali pada Sistem Pemeliharaan Semi Intensif di Daerah Lahan Kering
}

\author{
(Mating Pattern and Birth Estimate Based on Diagnosis Result of Bali Cattle Pregnancy \\ on Semi Intensive Maintenance System in Dry Land Areas)
}

\author{
Tarsisius Considus Tophianong ${ }^{1,2^{*}}$, Cynthia Dewi Gaina', Tri Utami ${ }^{1,2}$ \\ ${ }^{1}$ Laboratorium Klinik Reproduksi Patologi dan Nutrisi Fakultas Kedokteran Hewan, \\ Universitas Nusa Cendana, Kupang-NTT \\ ${ }^{2}$ Praktisi Dokter Hewan Pada Klinik Hewan Grace Vetcare Kupang-NTT \\ *Penulis untuk korespondensi: considus.tophianong@staf.undana.ac.id \\ Diterima 23 September 2020, Disetujui 15 Maret 2021
}

\begin{abstract}
ABSTRAK
Pola perkawinan dan kelahiran menjadi salah satu faktor penting dari manajemen reproduksi pada sistem pemeliharan semi intensif. Penelitian ini dilakukan untuk mengetahui pola perkawinan dan estimasi kelahiran berdasarkan hasil diagnosis kebuntingan sapi bali pada sistem pemeliharaan semi intensif padang penggembalaan di daerah lahan kering. Manfaat dari penelitian ini adalah sebagai data base dalam penerapan manajemen perkawinan. Sebanyak 208 ekor induk sapi bali di kelompok ternak Tamnau Amaf, Desa Bena, Kecamatan Amanuban Selatan, Kabupaten Timor Tengah Selatan, Provinsi NTT dilakukan anamnesa dan pemeriksaan per rektal pada tanggal 28-30 Mei 2019. Angka kebuntingan yang diketahui pada penelitian ini adalah $90.86 \%$ (189/208). Persentase usia kebuntingan tertua adalah usia kebuntingan 7 bulan 26,96\% (56/208). Berdasarkan data kebuntingan diketahui puncak pola perkawinan terjadi pada bulan Oktober 2018 dan estimasi kelahiran mencapai puncak pada bulan Juli 2019. Perkawinan sapi sebaiknya dilakukan pada kurun waktu bulan Januari - Maret sehingga kelahiran terjadi pada kurun waktu bulan Oktober - Desember. Perlu perbaikan manajemen perkawinan sapi bali pada sistem pemeliharaan semi intensif padang penggembalaan di daerah lahan kering sehingga kelahiran tidak terjadi pada puncak musim kemarau.

Kata kunci: Sapi bali, pola perkawinan, pola kelahiran, padang pengembalaan, semi intensif
\end{abstract}

\begin{abstract}
Mating pattern and birth is one of the important factor of reproductive management on semi intensive maintenance system. This study was conducted to determine mating pattern and birth estimate based on result of bali cattle pregnancy diagnosis on semi intensive maintenance system pastureland in dry land areas. The benefit of this study is as database on application of mating management. Totally 208 bali cattles at Tamnau Amaf farmer's group in Bena village, Amanuban Selatan District, Timor Tengah Selatan Regency, East Nusa Tenggara Province anamnesis was done and per rectal examination on 28-30 May 2019. Pregnancy rate has known on this study is $90.86 \%$ (189/208). The oldest of pregnancy age percentage is 7 months pregnancy $26,96 \%(56 / 208)$. Based on the pregnancy data, it is known the peak of mating pattern occurs on October 2018 and birth estimate peaked on July 2019. Cattle mating should be done in January-March period so the birth happened on October-Desember period. Needs to be improved bali cattle mating management on semi-intensive maintenance system pastureland in dry land areas so the birth do not happen in the peak of dry seasson.
\end{abstract}

Keywords: bali cattle, mating pattern, birth pattern, pastureland, semi-intensive 


\section{PENDAHULUAN}

Fakta membuktikan bahwa sistem pemeliharaan sapi Bali di NTT pada umumnya adalah sistem semi intensif tradisional tidak terencana, tidak tercatat dan tidak terukur. Sistem pemeliharaan ini merupakan sistem pemeliharaan sapi Bali dengan cara ditambat atau dilepas sejak pagi sampai sore di padang penggembalaan dan pada malam hari ditambat atau dikandangkan disekitar rumah peternak (Gambar 1). Pada siang hari peternak akan memindahkan lokasi tambat dengan maksud agar sapi mendapat pakan yang cukup di area yang baru. Sedangkan air minum akan dibawakan peternak atau peternak menggembalakan sapi ke sumber air pada siang atau sore hari. Ternak hanya memperoleh pakan dipadang penggembalaan milik kolektif (communal grazingland) tanpa pemberian pakan tambahan berupa konsentrat atau suplemen. Kualitas dan kuantitas pakan di padang penggembalaan sangat dipengaruhi oleh fluktuasi curah hujan (Gambar 1).

Pada sistem pemeliharaan yang demikian proses kehidupan sapi hampir sepenuhnya terjadi secara alami di padang penggembalaan sejak perkawinan sampai kelahiran. Pada sistem pemeliharaan semi intensif interaksi antara iklim, tanah, rumput sebagai pakan ternak dan ternak merupakan faktor-faktor yang mempengaruhi penampilan produksi maupun reproduksi ternak diantaranya aktivitas perkawinan (siklus estrus), angka kebuntingan dan kelahiran.

Menurut Chalid, (2002) kelahiran yang terjadi pada musim kemarau membawa dampak buruk terutama bagi pedet dalam hal pertumbuhan dan angka mortalitas pedet pasca sapih. Penelitian ini dilakukan untuk mengetahui pola perkawinan dan estimasi kelahiran berdasarkan hasil diagnosis kebuntingan sapi bali pada sistem pemeliharaan semi intensif di daerah lahan kering. Manfaat dari penelitian ini adalah sebagai data base dalam penerapan manajemen reproduksi terutama manajemen perkawinan.

\section{BAHAN DAN METODE}

\section{Rancangan Penelitian}

Sebanyak 208 ekor induk sapi bali di kelompok ternak Tamnau Amaf, Desa Bena Kecamatan Amanuban Selatan, Kabupaten Timor Tengah Selatan,

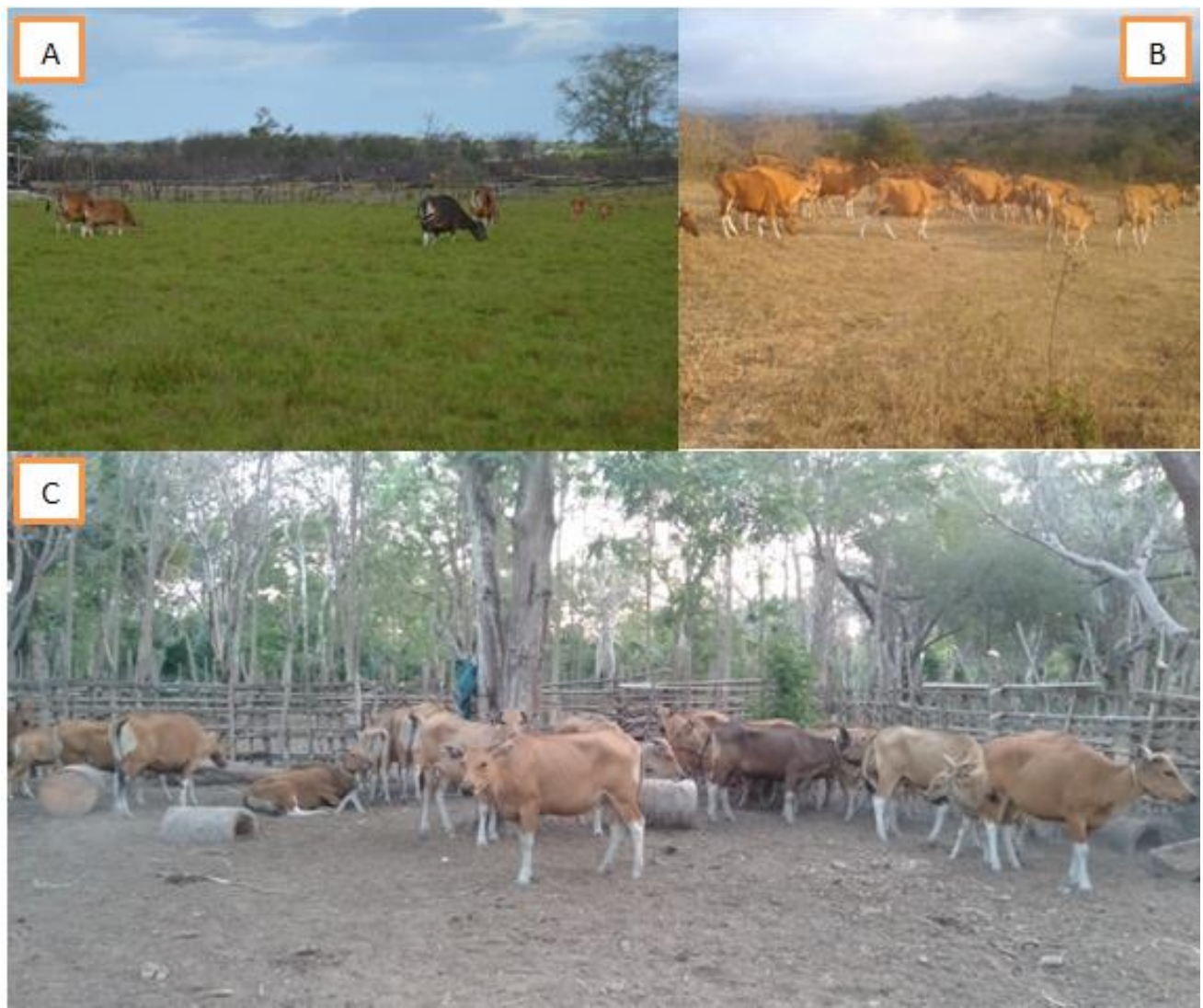

Gambar 1 Sistem pemeliharaan semi intensif; A. Kondisi padang pengembalaan saat musim hujan; B. Kondisi padang pengembalaan saat musim kemarau; C. Kandang kelompok saat malam hari 
Provinsi NTT dilakukan anamnesa dan pemeriksaan per rektal pada tanggal 28 - 30 Mei 2019. Sistem pemeliharaan sapi bali pada penelitian ini adalah semi intensif padang penggembalaan. Perkawinan terjadi secara alami antara sapi betina estrus dan pejantan dalam kelompok penggembalaan ditunjukkan pada Gambar 1.

Pemeriksaan kebuntingan dilakukan dengan metode per rektal lalu beberapa induk sapi bali dikonfirmasi menggunakan ultrasonografi (USG) transrektal sonodop, rektal linear probe frekuensi 6,5 Mhz. Penentuan diagnosis kebuntingan berdasarkan indikasi perubahan organ reproduksi dan tampilan pada monitor USG. Perubahan yang merupakan indikasi kebuntingan pada saat palpasi per rektal meliputi ukuran uterus, tekstur dan lokasi uterus, keberadaan cairan amion dan korioalantois dalam lumen uterus, desiran aliran darah arteri uterina mediana/ fremitus (Harry, 1990; Govind, 2010;
Jedrzej et.al, 2019); terabanya fetal membran slip, vesikel amnion, plasentom dan fetus (Robert, 2007; Govind, 2010; Whittier et.al, 2013; Natnael et.al, 2016; Alemayehu et.al, 2018).

Indikasi kebuntingan melalui pemeriksaan USG transrektal meliputi perbedaan ekogenisitas dari cairan akan berwarna hitam (anechoic) diantaranya cairan korioalantois dan jaringan padat diantaranya plasentom berwarna abu-abu (hypoechoic) (Whittier et. al, 2013). Indikasi kebuntingan melalui pemeriksaan per rektal meliputi ukuran fetus dan plasentom sangat bervariasi diantara bangsa sapi dan paritas, ukuran plasentom merupakan ukuran plasentom dari bangsa sapi Bos taurus dapat dilihat pada Tabel 1.

Angka kebuntingan diperoleh dari jumlah sapi yang bunting dibagi jumlah sapi yang diperiksa dikali $100 \%$. Hasil pemeriksaan status reproduksi (kebuntingan, postpartum, estrus) kemudian dicatat

Tabel 1 Indikasi kebuntingan dengan pemeriksaan per rektal

\begin{tabular}{|c|c|c|}
\hline Usia kebuntingan (Bulan) & Posisi uterus & Struktur yang di palpasi \\
\hline 1 & Lantai pelvis ${ }^{1,2,3,4,5,6,7}$ & $\begin{array}{l}\text { Uterus asimetris/membran slip/ vesikel } \\
\text { amnion }{ }^{1,2,3,4,5,6,7}\end{array}$ \\
\hline 2 & Lantai pelvis ${ }^{1,2,3,4,5}$ & $\begin{array}{l}\text { Uterus asimetris/ membran slip/ vesikel } \\
\text { amnion/ plasentom berukuran kecil. } \\
1,2,2,3,4,5,6,7\end{array}$ \\
\hline 3 & $\begin{array}{l}\text { Pelvis/ depan symphisis pu- } \\
\text { bis }\end{array}$ & $\begin{array}{l}\text { Plasentom (diameter } 1-1,5 \mathrm{~cm} \text { ), teraba } \\
\text { fetus, fremitus ipsilateral. } 1,2,3,4,5,6,6,7\end{array}$ \\
\hline 4 & Menurun ke abdomen $n^{1,2,3,4,5}$ & $\begin{array}{l}\text { Plasentom (diameter } 1.5-2.5 \mathrm{~cm} \text { ), teraba } \\
\text { fetus, fremitus ipsilateral. }{ }^{1,2,3,4,5,6,6,7}\end{array}$ \\
\hline 5 & Lantai abdomen ${ }^{1,2,3,4,5}$ & $\begin{array}{l}\text { Plasentom (diameter } 2.5-4 \mathrm{~cm} \text { ), fetus } \\
\text { kadang sulit teraba, cervix tertarik ke } \\
\text { cranio ventral, fremitus kontralateral. } \\
1,2,3,4,5,5,6,7\end{array}$ \\
\hline 6 & Abdomen $^{1}$ & $\begin{array}{l}\text { Plasentom (diameter } 4-5 \mathrm{~cm} \text { ), fetus } \\
\text { kembali teraba, fremitus kontrala- } \\
\text { teral }{ }^{1,2,6,7}\end{array}$ \\
\hline 7 & Mulai naik kearah dorsal ${ }^{1}$ & $\begin{array}{l}\text { Plasentom (diameter } 5-7.5 \mathrm{~cm} \text { ), pada } \\
\text { posisi anterior kepala dan tracak kaki } \\
\text { depan mulai mengarah ke pelvis, fremi- } \\
\text { tus kontralateral }{ }^{1,2,6,7}\end{array}$ \\
\hline 8 & $\begin{array}{l}\text { Naik hampir sejajar dengan } \\
\text { pelvis }^{1}\end{array}$ & $\begin{array}{l}\text { Plasentom (diameter } 6-8 \mathrm{~cm} \text { ), pada po- } \\
\text { sisi anterior, kepala dan tracak kaki de- } \\
\text { pan teraba sejajar dengan lantai pelvis, } \\
\text { fremitus kontralateral }{ }^{1,2,6,7}\end{array}$ \\
\hline 9 & Sejajar dengan pelvis ${ }^{1}$ & $\begin{array}{l}\text { Plasentom (diameter } 7-8.5 \mathrm{~cm} \text { ), pada } \\
\text { posisi anterior kepala dan tracak kaki } \\
\text { depan berada pada ruang pelvis, fremi- } \\
\text { tus kontralateral. }{ }^{1,2,6,7}\end{array}$ \\
\hline
\end{tabular}

Sumber: Robert, 2007'; Whittier et.al, 2013²; Alemayehu et.al, 20183; Jedrzej et.al, 20194; Brent and Albert, $2005^{5}$; Loide et.al; $2019^{6}$; Govind, $2010^{7}$. 
berdasarkan data hasil pemeriksaan status reproduksi (kebuntingan, postpartum dan estrus) pada bulan Mei 2019 selanjutnya dibuat perhitungan mundur untuk mengetahui pola perkawinan (satuan bulan) dan dihitung maju untuk mengetahui pola kelahiran (satuan bulan). Status postpartum dan usia pedet pada saat pemeriksaan dapat memberikan informasi terkait bulan kelahiran berdasarkan perhitungan mundur. Lama usia kebuntingan sapi adalah 9 bulan. Estimasi dari puncak kelahiran pada penelitian ini mengandaikan bahwa tidak adanya gangguan selama proses kebuntingan sehingga kebuntingan dapat berakhir dengan partus di akhir usia kebuntingan.

\section{Analisis Data}

Data hasil penelitian dianalisis secara deskriptif disajikan dalam bentuk tabel dan grafik.

\section{HASIL}

Hasil pemeriksaan status reproduksi sapi bali pada sistem pemeliharaan semi intensif di daerah lahan kering pada kelompok ternak Tamnau Amaf, Desa Bena Kecamatan Amanuban Selatan, Kabupaten Timor Tengah Selatan, Provinsi NTT dapat dilihat pada Tabel 2 dan Gambar 2.

Pada sistem pemeliharaan semi intensif padang penggembalaan dengan metode perkawinan alami tanpa rekording maka data rial yang berhubungan dengan estrus dan perkawinan adalah sesuatu yang sangat sulit diperoleh. Fakta membuktikan bahwa pada sistem pemeliharaan semi intensif dimana sapi jantan dan betina dicampur dalam berbagai kelompok usia, maka setiap sapi betina estrus sudah pasti langsung dikawini pejantan pada kelompok penggembalaan tanpa diketahui peternak. Berdasarkan uraian tersebut maka pola perkawinan dan estimasi kelahiran pada penelitian ini dihitung berdasarkan hasil diagnosis kebuntingan melalui pemeriksaan per rektal, post partus dan usia pedet yang terakhir dapat dilihat pada Tabel 3 dan Gambar 3 .

Metode pemeriksaan kebuntingan yang dilakukan pada penelitian ini adalah pemeriksaan per rektal dan beberapa ekor sapi diantaranya dilakukan USG transrektal sebagai penunjang diagnosis. Penunjang diagnosis dengan aplikasi USG dalam penelitian ini tidak dilakukan terhadap 208 ekor induk sapi karena sapi tersebut cukup liar serta ketiadaan listrik di lokasi penelitian (padang penggembalaan) ditunjukkan pada Gambar 4.

\section{PEMBAHASAN}

Berdasarkan Tabel 2 dan grafik pada Gambar 2 dapat diketahui bahwa status reproduksi sapi bali pada penelitian ini meliputi: bunting 2 bulan 5,28\%

Tabel 2 Status reproduksi berdasarkan hasil pemeriksaan per rektal

\begin{tabular}{llcc}
\hline No & & Status Reproduksi & \\
\hline & A. Bunting (usia) & Jumlah Sapi (N: 208 ekor) & $\%$ \\
1 & 1 bulan & - & - \\
2 & 2 bulan & 41,28 \\
3 & 3 bulan & 15 & 1,92 \\
4 & 4 bulan & 30 & 7,21 \\
5 & 5 bulan & 30 & 14,42 \\
6 & 6 bulan & 56 & 14,42 \\
7 & 7 bulan & 35 & 26,92 \\
8 & 8 bulan & 8 & 16,82 \\
9 & 9 bulan & & 3,84 \\
& & 11 & \\
\hline & B. Postpartus & 4 & 5,28 \\
2 & 1 bulan bulan & 3 & 1,92 \\
3 & 3 bulan & & 1,44 \\
\hline 1 & C. Estrus (Pedet terakhir umur & 1 & 0,48 \\
\end{tabular}




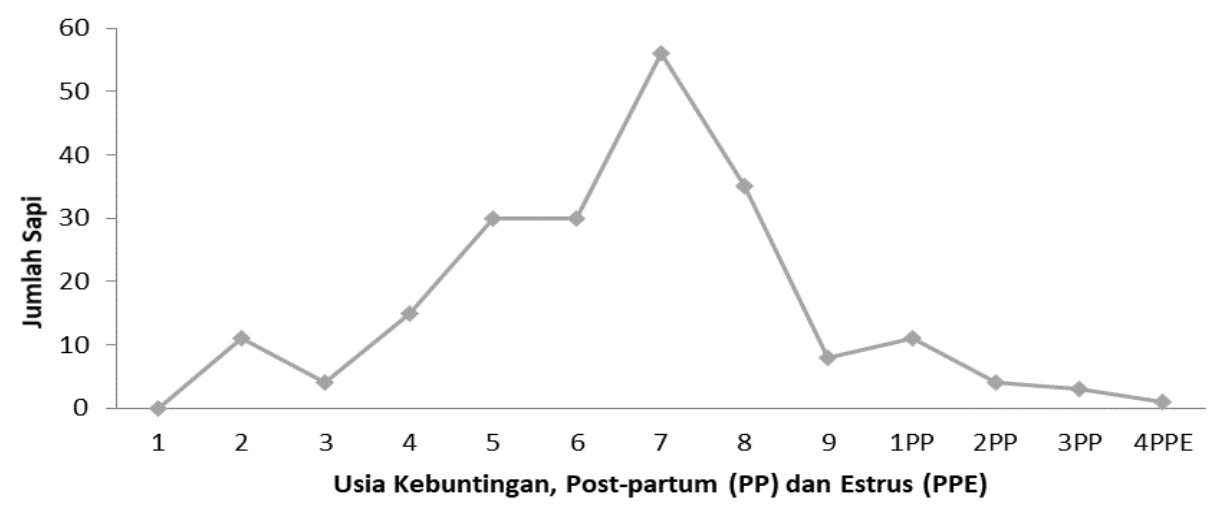

Gambar 2 Status reproduksi (bunting, post-partum dan estrus) berdasarkan hasil pemeriksaan per rektal 2830 Mei 2019, $1 \mathrm{PP}=1$ bulan post partum, $2 \mathrm{PP}=2$ bulan post partum, 3PP = 3 bulan post partum dan $4 \mathrm{PPE}=4$ bulan postpartum dan estrus pada saat pemeriksaan

Tabel 3 Pola perkawinan dan estimasi kelahiran berdasarkan hasil diagnosis kebuntingan

\begin{tabular}{lcc}
\hline Bulan & $\begin{array}{c}\text { Perkawinan } \\
\text { (ekor) }\end{array}$ & $\begin{array}{c}\text { Estimasi Kelahiran } \\
\text { (ekor) }\end{array}$ \\
\hline Januari & 15 & 1 \\
Februari & 4 & 3 \\
Maret & 11 & 4 \\
April & 1 & 11 \\
Mei & 3 & 8 \\
Juni & 4 & 35 \\
Juli & 11 & 56 \\
Agustus & 8 & 30 \\
September & 35 & 30 \\
Oktober & 56 & 15 \\
November & 30 & 4 \\
Desember & 30 & 11 \\
\hline
\end{tabular}

(11/208), bunting 3 bulan 1,92\% (4/208), bunting 4 bulan $7,21 \%$ (15/208), bunting 5 bulan $14,42 \%$ (30/208), bunting 6 bulan 14,42\% (30/208), bunting 7 bulan $26,92 \%$ (56/208), bunting 8 bulan $16,82 \%$ (35/208), bunting 9 bulan 3,84\% (8/208); Postpartus 1 bulan 5,28\% (11/208), postpartus 2 bulan 1,92\% (4/208), postpartus 3 bulan $1,44 \%$ (3/208), estrus (pedet terakhir umur 4 bulan) $0,48 \%$ (1/208). Hasil pemeriksaan per rektal pada beberapa ekor sapi dikonfirmasi menggunakan USG. Salah satu indikasi kebuntingan sapi berdasarkan peneguhan diagnosis menggunakan USG berupa peningkatan ekogenesitas (hipoechoik) jaringan plasentom yang terlihat pada monitor USG (Gambar 4). Angka kebuntingan yang diketahui pada penelitian ini adalah $90.86 \%$ (189/208). Persentase usia kebuntingan tertua yang ditemukan pada saat pemeriksaan adalah usia kebuntingan 7 bulan.
Persentase angka kebuntingan sapi bali pada sistem pemeliharaan semi intensif akan selalu dinamis dan bervariasi pada suatu kurun waktu, baik pada satu kelompok penggembalaan maupun pada kelompok penggembalaan yang berbeda. Angka kebuntingan pada pemeliharaan semi intensif padang penggembalaan dapat dipengaruhi oleh beberapa faktor diantaranya; (1). keberadaan pejantan dalam kelompok penggembalaan, karena kehadiran pejantan adalah sesuatu yang mutlak pada perkawinan sapi secara alami di padang penggembalaan; (2). pola curah hujan dan hari hujan yang mempengaruhi ketersediaan pakan di padang penggembalaan; (3). kesehatan sapi betina dan pejantan. Persentase angka kebuntingan yang diperoleh pada penelitian ini membuktikan bahwa sapi bali pada pemeliharaan semi intensif padang penggembalaan di daerah lahan kering memperlihatkan kemampuan adaptasi 


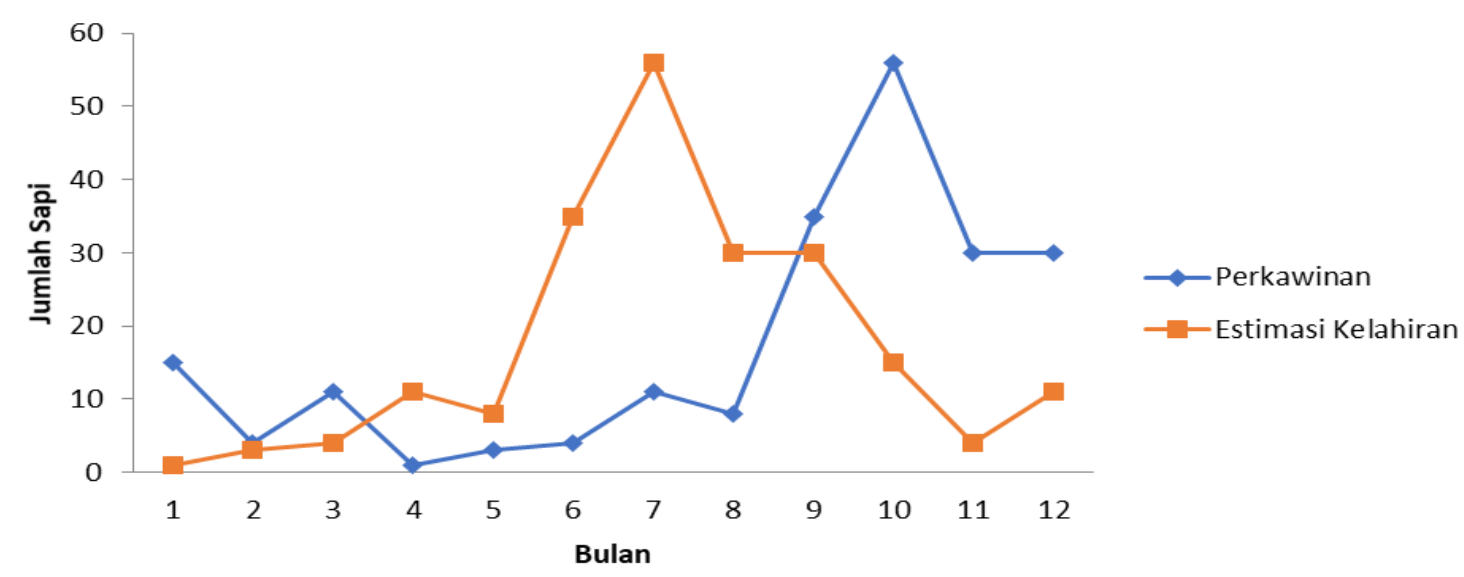

Gambar 3 Pola perkawinan dan estimasi kelahiran berdasarkan hasil diagnosis kebuntingan

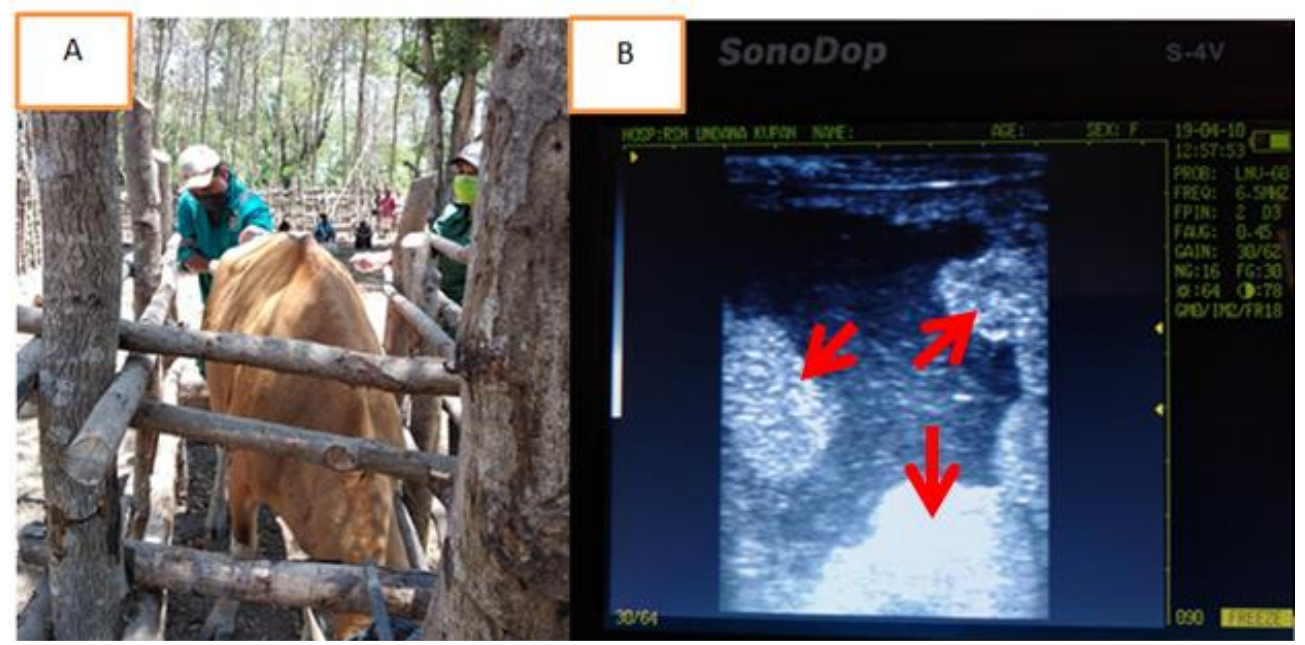

Gambar 4 Pemeriksaan per rektal (A), gambaran kotiledon tampak hipoechoik pada monitor USG ditandai panah merah (B)

terhadap fluktuasi ketersediaan pakan dan kinerja reproduksi yang superior diantaranya angka kebuntingan yang tinggi rata-rata $>80 \%$.

Sistem pemeliharaan semi intensif padang penggembalaan di daerah lahan kering bersifat spesifik lokasi. Nusa Tenggara Timur memiliki curah hujan yang rendah dan hari hujan yang pendek dengan musim kering selama 8 bulan dan musim hujan selama 4 bulan (BPS NTT 2014). Kondisi demikian akan mempengaruhi daya dukung wilayah terutama vegetasi rumput sebagai pakan ternak di padang penggembalaan. Padang penggembalaan di NTT pada umumnya padang pengembalaan alami yang didominasi oleh rumput dan legum tanpa intervensi manusia terhadap jenis dan jumlah vegetasi. Fluktuasi dan variasi ketersediaan jenis vegetasi di padang penggembalaan sangat di dikte oleh pola curah hujan (Gambar 1).

Puncak dari pola perkawinan pada penelitian ini diperoleh berdasarkan perhitungan mundur usia kebuntingan dari hasil diagnosis pada saat pemeriksaan per rektal dilakukan. Aktivitas reproduksi (estrus dan perkawinan) sapi Bali pada penelitian ini mulai meningkat pada bulan September tahun 2018 dan mencapai puncak pada bulan Oktober tahun 2018 (Tabel 3 dan Gambar 3). Rata-rata awal musim hujan di NTT terjadi di bulan Oktober, dengan demikian ketersediaan rumput dipadang penggembalaan dari sisi kualitas dan kuantitas tercukupi untuk kebutuhan aktivitas reproduksi yang ditandai 
dengan estrus dan perkawinan meskipun vegetasi rumput baru mulai tumbuh. Hal ini menunjukkan bahwa sapi bali sangat adaptif terhadap lingkungan padang penggembalaan yang kering seperti di NTT.

Pola aktivitas reproduksi yang ditandai dengan estrus dan perkawinan pada awal musim hujan merupakan bukti kemampuan adaptasi sapi bali terhadap fluktuasi ketersediaan rumput sebagai sumber pakan di padang penggembalaan. Ketersediaan rumput sebagai sumber pakan di padang penggembalaan pada awal musim hujan secara tidak langsung mempengaruhi aktivitas reproduksi. Menurut Rick (2007); Yugal et al. (2013); Rooh (2014) ketercukupan pakan baik kualitas maupun kuantitas akan mempengaruhi sintensis dan sekresi hormon reproduksi dalam regulasi fungsi normal siklus dan aktivitas reproduksi.

Pada Tabel 3 dan grafik pada Gambar 3 dapat diketahui bahwa estimasi puncak kelahiran terjadi pada bulan Juli 2019 (dengan asumsi tidak adanya gangguan selama proses kebuntingan). Puncak kelahiran pada penelitian ini hanya berupa estimasi berdasarkan usia kebuntingan dari hasil diagnosis pada saat pemeriksaan per rektal, post partus dan usia pedet yang terakhir. Puncak dari pola kelahiran pada penelitian ini hanya berupa estimasi karena sapi yang terdiagnosis bunting pada pemeriksaan ini tidak selalu berakhir dengan partus pada akhir kebuntingan. Menurut Amir and Nasroallah (2014) berbagai faktor yang dapat mempengaruhi proses kebuntingan diantaranya faktor infeksi dan non infeksi yang dapat mengakibatkan abortus dan prematur.

Pedet yang lahir pada bulan Juli mengalami tantangan besar terkait ketersediaan pakan di padang penggembalaan karena pada bulan tersebut NTT berada pada musim kemarau. Kualitas dan kuantitas pakan di padang penggembalaan sangat bergantung pada curah hujan setiap tahun. Pada musim kemarau, induk sapi akan terlihat mengalami penurunan body condition score (BCS).

Menurut Chalid (2002) penurunan BCS akan mengakibatkan penurunan mother ability yang meliputi penurunan produksi susu untuk memenuhi kebutuhan pedet. Penurunan BCS dan produksi susu pada induk sapi bali merupakan bagian dari proses adaptasi terhadap lingkungan terutama ketersediaan pakan. Kelahiran pedet pada musim kemarau pada saat produksi pakan di padang penggembalaan tidak mendukung, membawa dampak pada penurunan berat badan pedet, pertumbuhan pedet lambat dan kematian pedet pasca sapih mencapai $15 \%$ dari calving rate sebesar $83 \%$ (Chalid, 2002). Rumput sebagai sumber pakan merupakan vegetasi yang tumbuh dan mendominasi di padang penggembalaan pada musim hujan (4 bulan), sedangkan pada musim kemarau vegetasi tersebut cenderung mengering, mati dan berpotensi terjadinya kebakaran (Dwi, 2016).

Berdasarkan hasil penelitian ini dapat disimpulkan bahwa lingkungan padang penggembalaan merupakan faktor ekstrinsik yang mempengaruhi ketersediaan pakan, BCS, aktivitas reproduksi yang meliputi pola perkawinan dan kelahiran. Peternakan semi intensif padang penggembalaan bersifat spesifik lokasi, oleh karena itu manajemen pengembangannya harus berbasis wilayah. Perlu perbaikan manajemen perkawinan sapi bali pada sistem pemeliharaan semi intensif padang penggembalaan di daerah lahan kering. Perkawinan sapi sebaiknya dilakukan pada bulan Januari - Maret sehingga kelahiran tidak terjadi pada musim kemarau. Jika kelahiran terjadi pada bulan Oktober - Desember maka ketersediaan pakan di padang penggembalaan masih sangat memadai, dengan demikian kematian pedet pasca sapih akibat kekurangan pakan dapat diminimalisir.

"Penulis menyatakan tidak ada konflik kepentingan dengan pihak-pihak yang terkait dalam penelitian ini".

\section{UCAPAN TERIMAKASIH}

Kami menyampaikan terimakasih kepada Pimpinan dan staf dinas Peternakan dan Kesehatan Hewan Kabupaten Timor Tengah Selatan Provinsi NTT serta Para Peternak sapi pada kelompok ternak Tamnau Amaf, Desa Bena, Kecamatan Amanuban Selatan, Kabupaten Timor Tengah Selatan, Provinsi NTT .

\section{DAFTAR PUSTAKA}

Alemayehu hirpa, Belete Yehualaw, Atilaw Wube, Abebe Asnake and Abraham Jemberu, 2018. Review on Pregnancy Diagnosis in Dairy Cows. Journal of Reproduction and Infertility 9 (2): 44-55, 2018.

Amir Hossein Asgari Safdar and Nasroallah Moradi Kor, 2014. Parturition Mechanisms in Ruminants: complete overview. Pelagia Research Library. European Journal of Experimental Biology, 4(3): 2011-2018. 
Badan Pusat Statistik Nusa Tenggara Timur (BPS NTT). 2014. Nusa Tenggara Timur dalam Angka, BPS NTT, Kupang.

Brent Broaddus1, MS, and Albert de Vries2, PhD, 2005. A Comparison of Methods for Early Pregnancy Diagnosis. Proceedings 2nd Florida Dairy Road Show (2005).

Chalid Talib, 2002. Sapi Bali di Daerah Sumber Bibit dan Peluang Pengembangannya. Wartazoa Vol.12 No.3 Tahnun 2002.

Dwi Priyanto, 2016. Strategi Pengembalian Wilayah Nusa Tenggara Timur Sebagai Sumber Ternak Sapi Potong. Jurnal Litbang Pertanian Vol.35 No.4 Desember 2016: 167-178.

Govind Purohit, 2010. Methods Of Pregnancy Diagnosis In Domestic Animals: The Current Status. Webmedcentral > Review articles Downloaded from http:// www.we bmed central.com on 10Dec-2010, 07:37:00 PM

Harry Momont, 1990. Rectal Palpation: Safety Issues. The Bovine Practioner No.25. Downloads/2309Article\%20Text-1936-1-11-20190819.pdf

Jedrzej M Jaskowski, Michal Kaczmarowski, Jakub Kulus, Bartlomiej M Jaskowski, Magdalena Herudzinska, Marek Gehrke, 2019. Rectal Palpation for Pregnancy in Cows: A relic or an alternative to Modern Diagnostic Methods. Med.Weter. 75(5), 259-264.
Loide Valadao, Helena Moreira da Silva and Fernando Moreira da Silva, 2019. Bovine Embrionic Development to Implantation. DOI: 10.5772/intecho pen.80655.https://www.researchgate.net/public ation/330292329

Rick Funston, 2007. Nutrition and reproduction interactions. Proceedings, Applied Reproductive Strategies in Beef Cattle, Montana.

Rooh UI Amin, 2014. Nutrition: Its role in reproductive functioning of cattle-a review, Veterinary Clinical Science. January-March Vol 2, Issue 1, Pages 01-09 Jakraya Publications (P) Ltd.

Roobert S Youngquist, 2007. Pregnancy Diagnosis in Current Therapy in Large Animal Theriogenocology 2. Saunders Elsevier.

Natnael Bekele, Mekeonnen Addis, Nejash Abdela and Wahid M.Ahmed, 2016. Pregnancy Diagnosis in Cattle For Fertility Management: A Review. Global Veterinaria 16 (4): 355-364.

Yugal Raj Bindari, Sulochana Shrestha, Nabaraj Shrestha and Tara Nath Gaire, 2013. Effects of nutrition on reproduction- A review. Pelagia Research Library, Advances in Applied Science Research, 2013, 4(1):421-429

Whittier, 2013. Pregnancy Determination in Cattle: a Review of Available Alternatives. Proceeding Applied Reproductive Strategies in Beef Cattle.Oktober 15-16, 2013. 